\title{
Phytochemical properties, antibacterial and anti-free radical activities of the phenolic extracts of Retama raetam (Forssk) Webb. \& Berthel. collected from Algeria Desert
}

\author{
Atef CHOUIKH ${ }^{* 1,2}$ and Fatma ALIA ${ }^{1,2}$ \\ ${ }^{1}$ Biology Department, Faculty of Natural Science and Life, El Oued University, El Oued, Algeria \\ ${ }^{2}$ Laboratory Biology, Environment and Health (LBEH), El Oued University, El Oued, Algeria
}

\begin{abstract}
This study aimed to evaluate the phytochemical properties, antibacterial and anti free-radical activities of Retama raetam extracts which is growing in the South-East of the Algeria Desert. The chemical screening showed the presence of many secondary metabolites such as tannins catechin, sterols and terpenes, and the absence of gallic tannins compounds. The obtained results demonstrated that the methanolic extract has shown moderate total phenolic and flavonoids contents ( $31.59 \pm 2.82 \mathrm{mg} \mathrm{AG} \mathrm{E} / \mathrm{g}$ extract and $14.35 \pm 1.02 \mathrm{mg} \mathrm{Qu} \mathrm{E} / \mathrm{g}$ extract respectively). In the free radical $\mathrm{DPPH}$ test, the values of $\mathrm{IC}_{50}$ were converging in all extracts of $R$. raetam. The antibacterial activity of extracts has been tested against ten bacterial strains, were registered as the best inhibition zones with Vibrio cholera, Micrococcus luteus and Serratia marcescen. Pseudomonas aeruginosa ATCC 27853 and Staphylococcus aureus ATCC 25923 strains showed high resistance against most of all concentrations of extracts, and we noted the Gram-negative bacteria strains are the most sensitive to the different extracts of the plant. The qualitative analysis of extracts by using HPLC showed the contrast in presence of the phenolic compounds, such as in ethyl acetate extract registered absence of chlorogenic acid, also the absence of caffeic acid in 1-butanol extract. These results confirmed of the phenolic extracts of this plant are a source natural alternative to antibiotics and antioxidants.
\end{abstract}

Keywords: Retama raetam; anti-free radical activity; antibacterial activity; HPLC.

\section{Introduction}

The abundance of active ingredients gives the plant remarkable pharmacological properties, which could justify its multiple therapeutic indications and for which it is used in traditional therapy [1].

Retama raetam (Frosk) Webb. \& Berthel. (Fabaceae) is a perennial plant widely distributed in the North Africa and Mediterranean area [2-4]. In folk medicine of Algeria, the $R$. raetam used to treat stomach malady, inflammation and diabetic disease [5]. The antibacterial, antifungal and cytotoxic activities of two flavonoids licoflavone $\mathrm{C}$ and derrone isolated from Retama raetam flowers were evidenced. They were active against Pseudomonas aeruginosa and Escherichia coli and showed important antifungal activity as for example found with derrone. The tested compounds also showed strong cytotoxicity against Hep-2 cells [6]. Also, Edziri et al. [7] confirmed the essential oils from the flowers of Retama raetam collected from Tunisia possesses compounds with antibacterial, antifungal and antioxidant capacities.

The chemical screening of a plant reveals the importance of the secondary metabolites, which play very important roles in the plant, i.e. against microbial and fungal attacks, antioxidants against various environmental stresses, attract pollinators, reserves and alienation of herbivores [8].

For identifies and quantification of some metabolites secondary and research a new source natural alternative to antibiotics and antioxidants in plants desertic, this study aims to estimate the phytochemical properties, antioxidant and antibacterial activities of crude, flavonoids and tannins extracts of $R$. raetam growing in the Algeria Desert.

\section{Experimental}

\subsection{Materials}

Plant material. The aerial part of $R$. raetam was collected from the Oued Souf region (South-East of Algeria Sahara).

\subsection{Chemicals}

Methanol $(\mathrm{MeOH})$ and dichloromethane were purchased from Biochem Chemophara (Montreal, Quebec, Canada); ethyl acetate, 1-butanol, acetone, DMSO, 2,2-diphenyl-1-picrylhydrazyl (DPPH), FolinCiocalteu reagent, aluminum chloride $\left(\mathrm{AlCl}_{3}\right)$, sodium carbonate $\left(\mathrm{Na}_{2} \mathrm{CO}_{3}\right)$, gallic acid, quercetin, and ferric chloride $\left(\mathrm{FeCl}_{3}\right)$ were purchased from Sigma Aldrich, Chemicals Co (St. Louis, MO, USA).

\subsection{Methods}

2.3.1. Chemical screening. The plant was tested for the presence of bioactive compounds such as flavonoids, tannins, anthocyanins, alkaloids, saponins, sterols and terpenes following standard procedures [9-11].

\footnotetext{
* Corresponding author. E-mail addresses: atef-chouikh@univ-eloued.dz; atchouikh@ yahoo.fr (A. Chouikh)
} 


\subsubsection{Preparation of the extracts}

Methanolic extract. $50 \mathrm{~g}$ of the dried plant were macerated in $500 \mathrm{~mL}$ of $\mathrm{MeOH}$ at room temperature in dark for $24 \mathrm{~h}$. The solvent was evaporated under reduced pressure at $60{ }^{\circ} \mathrm{C}$ by rotary evaporator type Buchi R-200 [12].

Extraction of flavonoids. According to Bekkara et al. [13], $30 \mathrm{~g}$ of the plant were macerated in $300 \mathrm{~mL}$ of $\mathrm{MeOH}$ for $24 \mathrm{~h}$. After filtration and evaporation of the solvent, the first extraction was obtained with $150 \mathrm{~mL}$ of hot water and $150 \mathrm{~mL}$ of ethyl acetate (2 times). In the second extraction were added $150 \mathrm{~mL}$ of 1-butanol ( 2 times) in the aqueous phase. The two organic phases (ethyl acetate and 1-butanol) were evaporated in a rotary evaporator device to obtain two phases of flavonoids, i.e. ethyl acetate and 1-butanol.

Extraction of tannins. According to the method citing in Zhang et al. [14], $30 \mathrm{~g}$ of the dried plant were macerated in $300 \mathrm{~mL}$ of the water/acetone $(7 \mathrm{~V} / 3 \mathrm{~V})$ in dark and room temperature for 3 days. After the filtration, the acetone was evaporated and the aqueous layer was extracted respectively with dichloromethane and ethyl acetate $(2 \times 180 \mathrm{~mL})$. The organic phase was dried to give the tannins extract.

2.3.3. Estimation of total polyphenols content. The total polyphenols in the crude extracts were determined by using Folin-Ciocalteau reagent with the method of [15]. $200 \mu \mathrm{L}$ of extract were mixed with $1 \mathrm{~mL}$ of FolinCiocalteu reagent $(10 \%)$ and $800 \mu \mathrm{L}$ of $\mathrm{Na}_{2} \mathrm{CO}_{3}(7.5$ $\%)$. The mixtures were incubated for $30 \mathrm{~min}$ at room temperature and protected from light. They were read at $765 \mathrm{~nm}$ in a spectrophotometer (type Shimadzu). The calibration curve was prepared with gallic acid solutions in the concentration range of $0.02-0.12 \mathrm{mg} / \mathrm{mL}$. The total polyphenols content was expressed in $\mathrm{mg}$ equivalent of gallic acid (GA) per gram of extract.

2.3.4. Quantification of flavonoids. The flavonoids content was determined by using $\mathrm{AlCl}_{3}$ according to the method of Ordonez et al. [16]. $0.5 \mathrm{~mL}$ of crude extract were mixed with $0.5 \mathrm{~mL}$ of $\mathrm{AlCl}_{3}(2 \%)$. The mixture remained at room temperature for $15 \mathrm{~min}$; the absorbance was measured at $420 \mathrm{~nm}$ with a spectrophotometer. The calibration curve was prepared with quercetin solutions in the concentration range of $0.03-0.1 \mathrm{mg} / \mathrm{mL}$. The content was expressed in $\mathrm{mg}$ equivalent of quercetin $(\mathrm{Qu})$ per gram of extract.

2.3.5. HPLC analysis. In this work, we used a HighPerformance Liquid Chromatography (HPLC) system, type Shimadzu LC 20 AL equipped with an universal injector (Hamilton $25 \mu \mathrm{L}$ ). The analytical column used was a Shim-pack VP-ODS C18 $(4.6 \mathrm{~mm} \times 250 \mathrm{~mm}, 5$ $\mu \mathrm{m})$, type Shimadzu. An UV-VIS detector SPD 20A (Shimadzu) was used. The mobile phase was a mixture of acetonitrile and acetic acid $0.1 \%$. The contents of the mobile phase were filtered before use through a $0.45 \mu \mathrm{m}$ membrane filter, sonicated and pumped from the solvent reservoir to the column at a flow rate of $1 \mathrm{~mL} / \mathrm{min}$. according to Chouikh et al. [17], and $20 \mu \mathrm{L}$ of plant extracts solution were injected into the flow of the mobile phase. We adjusted the high pressure that drives the mobile phase by using a pump. The separated compounds shall be determined using the column for
40-50 min with the mobile phase in the effluent detected at $\lambda=268 \mathrm{~nm}$ and to the computer which records the results as chromatographic curves. In this study, the quantification of some peaks was compared by calibration of standards: ascorbic acid, gallic acid, chlorogenic acid, caffeic acid, vanillin, $p$-coumaric acid and rutin (Figure 1).

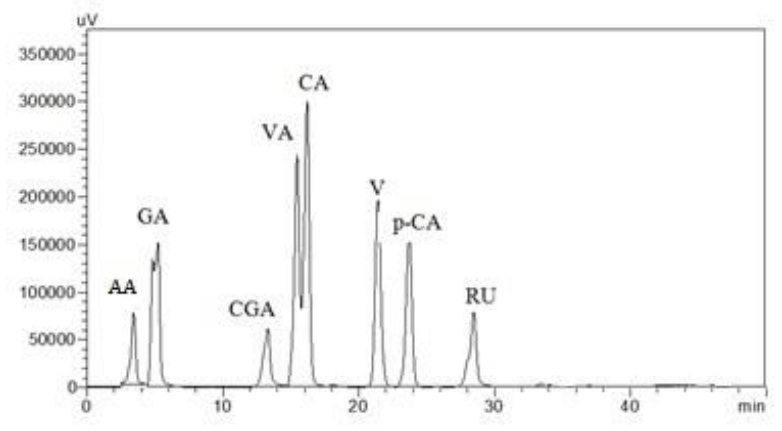

Figure 1. The High Performance Liquid Chromatography (HPLC) chromatogram of standard phenolic compounds. AA — ascorbic acid; GA — gallic acid; CGA — chlorogenic acid; VA—vanillic acid; CA — caffeic acid; V—vanillin; p$\mathrm{CA}-p$-coumaric acid; $\mathrm{RU}$-rutin.

2.3.6. Free radical DPPH scavenging activity. According to the method of Brand-Williams et al. [18], free radical scavenging activity was measured with DPPH. $1 \mathrm{~mL}$ of different concentrations of extracts was mixed with $1 \mathrm{~mL}$ methanol containing DPPH $\left(10^{-4} \mathrm{M}\right)$ and incubated in the dark for $15 \mathrm{~min}$. The absorbance was measured at $517 \mathrm{~nm}$ with an UV-Vis spectrophotometer. The ascorbic acid standards were prepared for positive comparison. The percentage of inhibition was calculated by using the following formula:

$$
I \%=\frac{A_{c}-A_{s}}{A_{c}} \times 100
$$

$A_{c}=$ absorbance of the control;

$A_{s}=$ absorbance of the sample.

The $\mathrm{IC}_{50}$ values were calculated from the linear equation of scavenging activity against the concentrations of the samples. $\mathrm{IC}_{50}$ is defined as the total antioxidant necessary to decrease by $50 \%$ DPPH free radical [19].

2.3.7. Antibacterial activity. Ten strains of bacteria were used in antibacterial activity. The six strains Gramnegative are: Escherichia coli ATCC 25922, Pseudomonas aeruginosa ATCC 27853, Enterobacter cloacae, Salmonella enterica, Serratia marcescens and Vibrio cholerae, and the four strains Gram-positive: Staphylococcus aureus ATCC 25923, Bacillus subtilis, Staphylococcus epidermidis and Micrococcus luteus. For positive comparison, three antibiotics were used: Gentamicin $\mathrm{HLG}_{120}(120 \mu \mathrm{g} / \mathrm{dish})$, Nitroxoline (30 $\mu \mathrm{g} / \mathrm{dish})$ and Cephalexin $\mathrm{CN}_{30}(30 \mu \mathrm{g} / \mathrm{dish})$.

The antimicrobial activity of the extracts of $R$. raetam was evaluated by using the disc diffusion method as reported by [20, 21]. Each strain of bacteria was inoculated in Mueller-Hinton agar. Sterile paper discs of $6 \mathrm{~mm}$ diameter were impregnated with $10 \mu \mathrm{L}$ of various concentrations $(0.25,0.5,1$, and $2 \mathrm{mg} / \mathrm{mL})$ of each extract [22]. Empty sterile discs and discs 
impregnated with DMSO were used as negative controls. The Petri dishes were incubated at $37{ }^{\circ} \mathrm{C}$ for 24 h. After this, the diameter of the inhibition zone of each disc was measured [23].

\section{Results and discussion}

\subsection{Chemical screening}

The results of the phytochemical screening of the aerial parts of $R$. raetam are given in Table 1. Preliminary chemical screening showed most secondary metabolites with the recording of the absence of gallic tannins.

Table 1. Phytochemical screening of the aerial parts of $R$. raetam

\begin{tabular}{|c|c|c|}
\hline $\begin{array}{c}\text { Secondary } \\
\text { metabolites }\end{array}$ & Observation & Results \\
\hline Flavonoids & Red color & + \\
\hline Tannins catechin & Bluish-green color & + \\
\hline Tannins gallic & $\begin{array}{c}\text { Not appear black } \\
\text { color }\end{array}$ & - \\
\hline Anthocyanins & Pink color & + \\
\hline Alkaloids & White precipitate & + \\
\hline Sterols and Terpenes & Purple ring & + \\
\hline Saponosides & $\begin{array}{c}\text { Forms foam in all } \\
\text { tubes }\end{array}$ & + \\
\hline
\end{tabular}

(+) Presence; (-) Absence.

Phytochemical screening with color reaction method was conducted to determine the group of secondary metabolites in the sample. These tests facilitate their quantitative estimation and qualitative separation. Phytochemical screening experiments are commonly performed to promote a guidance of substantial phytochemicals that may be involved in the biological functions of plants [24]. On the other hand, this variation can be linked to the distribution of secondary metabolites, which changes during plant development, environmental stress (drought, poor soil nutrients) as well as strong sunlight [25].

\subsection{Yield and properties of extracts}

Among the extracts of $R$. raetam, the methanol extract $(8.80 \%)$ has a higher yield compared to other extracts (Table 2). The extraction solvents influence the extraction yield and the content of bioactive compounds [26]. In this study, the different yield of extracts can return to solvents types and their polarity, a successful determination of biologically active compounds from plant material being largely dependent on the type of solvent used in the extraction procedure [27].

Table 2. Properties of the extracts of $R$. raetam aerial part

\begin{tabular}{|c|c|c|c|}
\hline Extracts & Nature & Color & Yield (\%) \\
\hline $\begin{array}{c}\text { Methanol } \\
\text { extract }\end{array}$ & Dough solid & Blackish green & 8.80 \\
\hline $\begin{array}{c}\text { Extract of } \\
\text { flavonoids } \\
\text { phase ethyl } \\
\text { acetate }\end{array}$ & Dough & Dark brown & 2.43 \\
\hline $\begin{array}{c}\text { Extract of } \\
\text { flavonoids } \\
\text { phase 1- } \\
\text { butanol }\end{array}$ & Viscous & Umber & 3.07 \\
\hline $\begin{array}{c}\text { Tannins } \\
\text { Extract }\end{array}$ & Dough solid & Blackish green & 0.60 \\
\hline
\end{tabular}

\subsection{Quantification of polyphenols and flavonoids in the crude extract}

$31.59 \pm 2.82 \mathrm{mg}$ gallic acid equivalents per gram of extract for polyphenols and $14.35 \pm 1.02 \mathrm{mg}$ of quercetin equivalents per gram of extract for flavonoids were determined for crude extract.

The amount of phenolic compounds and flavonoids changes from one extract to another according to the type of compounds, as their behavior varies according to their chemical structure and the medium in which they are present $[28,29]$. The total content of phenolics or flavonoids is controlled by many parameters and conditions, one of them being the environmental factors in which plant grows such as the season and date of collecting, soil composition, climate, temperature, light, humidity and stress $[30,31]$.

\subsection{HPLC analysis}

The HPLC chromatograms of different extracts of $R$. raetam are presented in Figures 2-4. The comparison of the retention time with standards resulted in a difference in the number and concentration of compounds per extract.

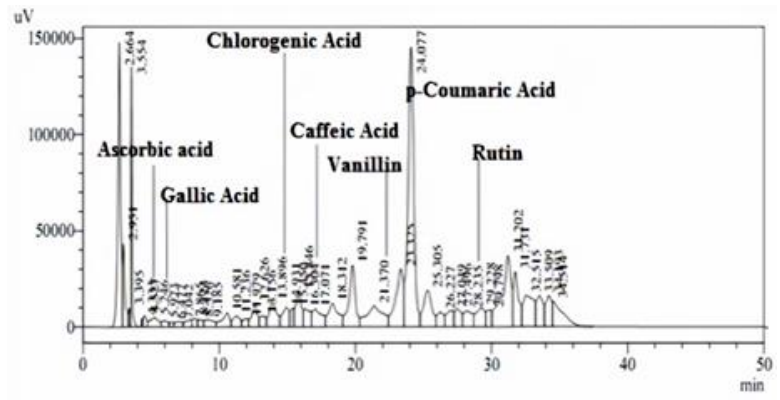

Figure 2. HPLC chromatogram of methanol extract of $R$.

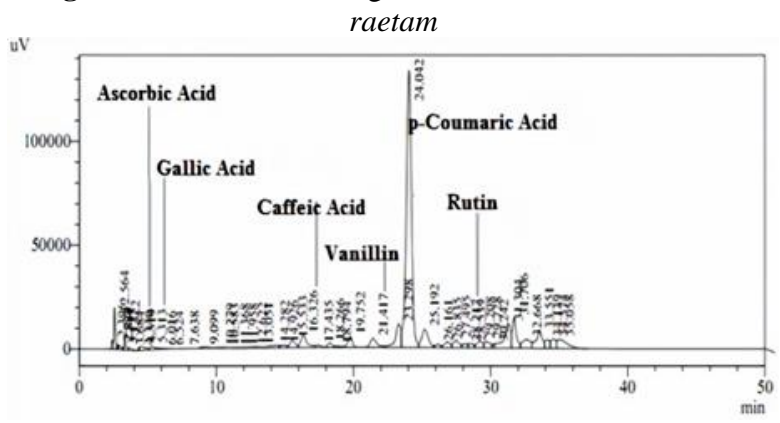

Figure 3. HPLC chromatogram of flavonoids extract phase ethyl acetate of $R$. raetam

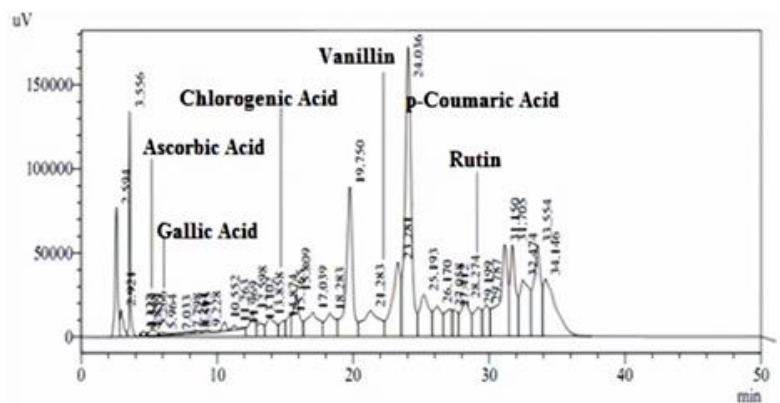

Figure 4. HPLC chromatogram of flavonoids extract phase 1-butanol of $R$. raetam

The concentrations of phenolic compounds in studied extracts are shown in Table 3. We managed the identification of seven compounds in methanol extract (ascorbic acid, gallic acid, chlorogenic acid, caffeic acid, 
vanillin, $p$-coumaric acid, and rutin), but in extract ethyl acetate was showed the absence of chlorogenic acid, and also the absence of caffeic acid in 1-butanol extract.

Table 3. The concentration ( $\mu \mathrm{g} / \mathrm{mg}$ extract) of major phenolic compounds identified by HPLC in extracts of $R$. raetam

\begin{tabular}{|c|c|c|c|}
\hline & $\begin{array}{c}\text { Methanol } \\
\text { extract }\end{array}$ & $\begin{array}{c}\text { Flavonoids } \\
\text { extract } \\
\text { phase ethyl } \\
\text { acetate }\end{array}$ & $\begin{array}{c}\text { Flavonoids } \\
\text { extract } \\
\text { phase 1- } \\
\text { butanol }\end{array}$ \\
\hline Ascorbic acid & 14.705 & 10.286 & 8.436 \\
\hline Gallic acid & 0.949 & 0.385 & 0.563 \\
\hline $\begin{array}{c}\text { Chlorogenic } \\
\text { acid }\end{array}$ & 1.209 & - & 1.333 \\
\hline Caffeic acid & 0.422 & 0.497 & - \\
\hline Vanillin & 1.070 & 0.340 & 1.531 \\
\hline $\begin{array}{c}\text { p-Coumaric } \\
\text { acid }\end{array}$ & 2.644 & 4.257 & 3.356 \\
\hline Rutin & 1.467 & 0.410 & 4.035 \\
\hline
\end{tabular}

The methanol extracted a higher number of compounds when compared to other extracts. According to Marco et al. [32] and Visioli et al. [33], it was demonstrated that ethyl acetate is somewhat selective towards low and medium molecular mass phenolic compounds. Onother hand, the caffeic acid is absent in the flavonoids extract phase 1-butanol, this being in accordance with a study of [34].

\subsection{Free radical DPPH scavenging activity}

The $\mathrm{IC}_{50}$ values (Figure 5) showed converging values of radical scavenging activity at extract of tannins $(0.223$ $\mathrm{mg} / \mathrm{mL})$, methanol extract $(0.232 \mathrm{mg} / \mathrm{mL})$ and flavonoids phase ethyl acetate extract $(0.247 \mathrm{mg} / \mathrm{mL})$,
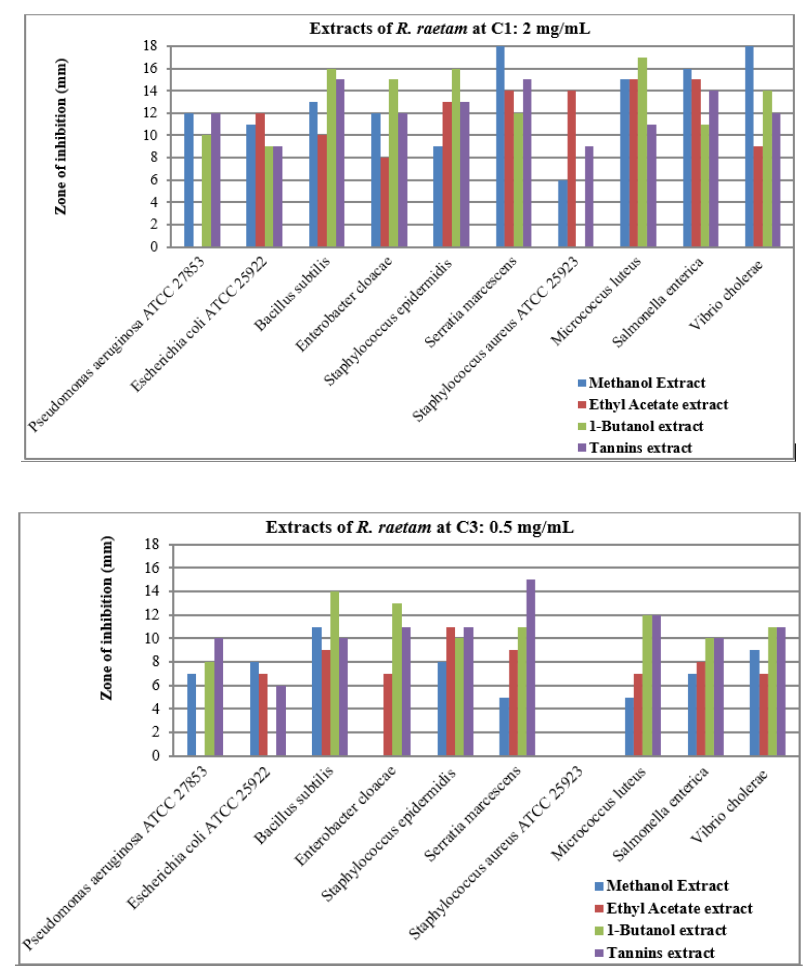

whereas the less scavenging activity was showed for extract of flavonoids phase 1-butanol $(0.344 \mathrm{mg} / \mathrm{mL})$.

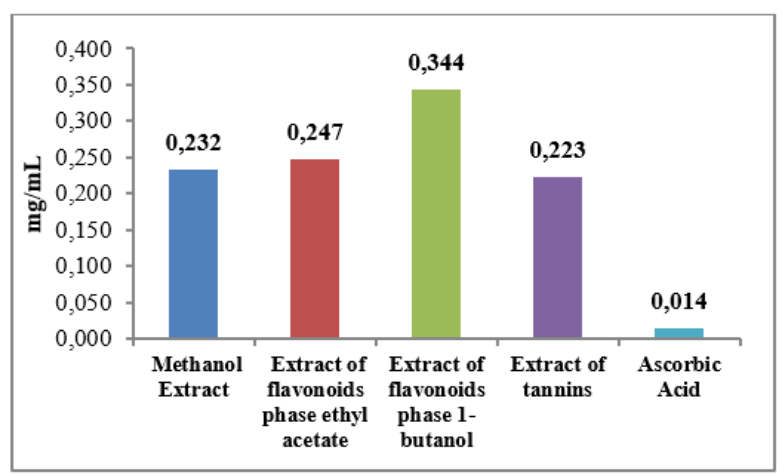

Figure 5. IC50 values $(\mathrm{mg} / \mathrm{mL})$ of DPPH radical scavenging activity of the different extracts of $R$. raetam and ascorbic acid

The secondary metabolites are characterized by the presence of several phenol groups in their structure. Most of these groups are active in scavenging free radicals due to their ability to donate a hydrogen atom or an electron $[35,36]$. In this study, the results indicate a direct relationship between the total content of polyphenols and flavonoids, and the antioxidant capacity; this was confirmed by [37]. Besides, the DPPH test revealed that the tannins extract possessed a good antioxidant capacity. This suggests that extract contains secondary metabolites with strong antioxidant activity [16] and medium molecular mass phenolic compounds.

\subsection{Antibacterial activity}

The antibacterial activity of the different extracts of $R$. raetam was determined against 10 bacterial strains (Figure 6).
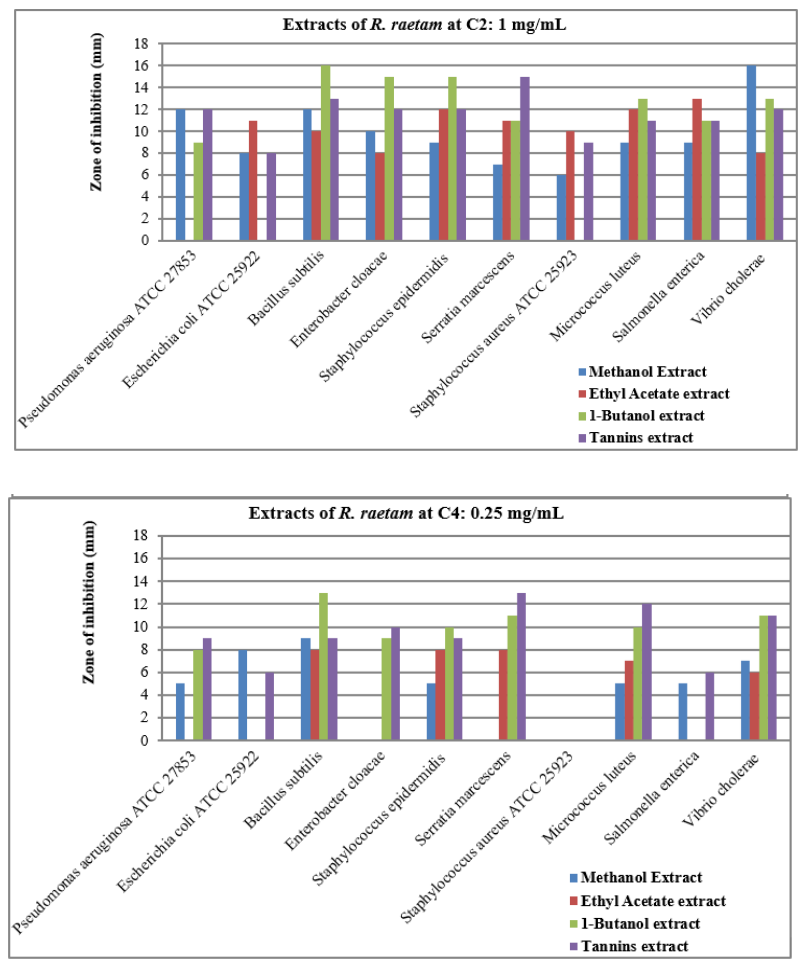

Figure 6. Antibacterial activity of the different concentrations of extracts of R. raetam

The inhibition zone, measured in millimeters, was reported after $24 \mathrm{~h}$ of incubation time, showing that the tested extracts could be classified according to their activity. The strongly active compounds included the 
extract of tannins with a mean antimicrobial growth, the second most active extract against bacteria strains beings that in methanol extract. The third active extract was an extract of flavonoids phase 1-butanol, whereas the flavonoids extract phase ethyl acetate was less active.

The antibiotics used in antibacterial activity showed the best activity than all extracts of $R$. raetam, as the inhibition diameters from 0-35 mm (Figure 7).

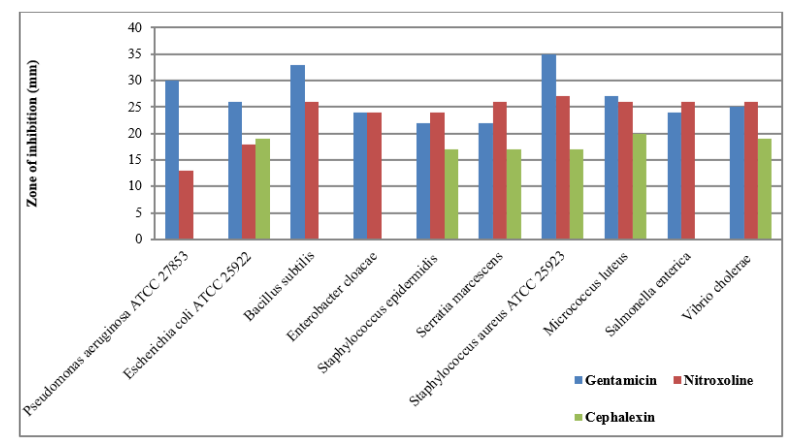

Figure 7. Antibacterial activity of the used antibiotics

Generally, these data indicate that Gram-negative bacteria are the most sensitive to the different extracts compared to Gram-positive bacteria (Figure 8).

In the antibacterial activity of the extracts, they can be associated with major constituents of all extracts. The research on the antimicrobial activity of phenolic compounds suggests that they diffuse into and damage cell membrane structures [38]. Whereas, the difference between bacteria of Gram-negative and Gram-positive can return to the structure, composition and nature of the walls [39].

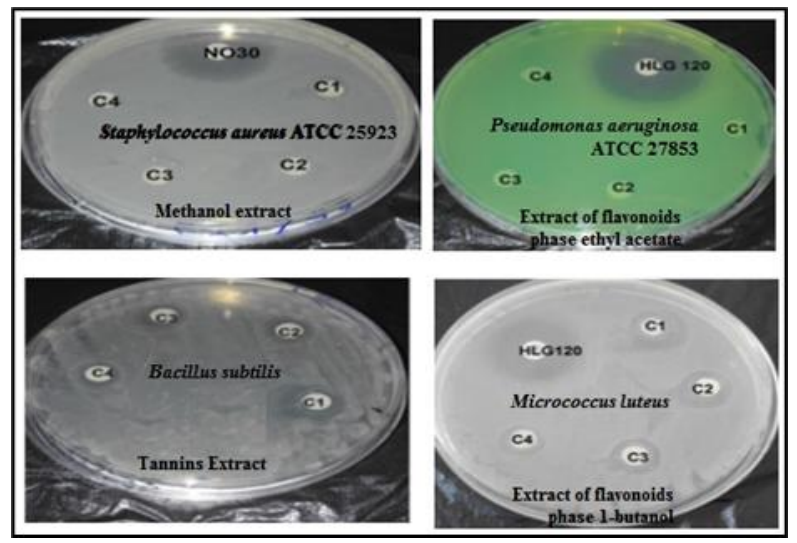

Figure 8. Antibacterial activity of the different concentrations of extracts of $R$. raetam against some bacteria strains

\section{Conclusions}

In this work, we evaluated the phytochemical properties, antibacterial and anti-free radical activities of phenolic extracts of Retama raetam. The chemical screening showed the presence of many secondary metabolites, the analysis of extracts by HPLC showed the appearance of six phenolics compounds and the absence of chlorogenic acid in ethyl acetate extract and caffeic acid in 1-butanol extract. In the free radical DPPH test, the values of $\mathrm{IC}_{50}$ were converging in all extracts of $R$. raetam, and from the results of the antibacterial activity we noted the Gram-negative bacteria strains are the most sensitive to the extracts of the plant. These results confirmed that the plant is an alternative source of natural antibiotics and antioxidants.

\section{Conflict of interest}

The authors declare no conflict of interest.

\section{Acknowledgment}

The authors would like to gratefully thank Dr. REBIAI Abdelkrim (VTRS Laboratory, El Oued University, Algeria) for HPLC Chromatographic analysis.

\section{References}

[1]. N.G. Konkon, D. Simaga, A.L. Adjoungova, K.E. N'Guessan, G.N. Zirihi, B.D. Koné, Etude phytochimique de Mitragyna inermis (Willd.) O. Ktze (Rubiaceae), plante a feuille antidiabetique, Pharmacopée et médecine traditionnelle africaine 14 (2006) 73-80.

[2]. P. Ozenda, Flore du Sahara, $2^{\text {ème }}$ Ed., CNRS, Paris, 1977.

[3]. P. Ozenda, Flore du Sahara, $3^{\mathrm{ème}}$ Ed., CNRS, Paris, 1991.

[4]. S. Quezel, S. Santa Nouvelle flore de l'Algérie et des régions désertique méridionales, CNRS, Paris, 1963.

[5]. R. Azzi, R. Djaziri, F. Lahfa, F.Z. Sekkal, H. Benmehdi, Belkacem, N. Ethnopharmacological survey of medicinal plants used in the traditional treatment of diabetes mellitus in the North Western and South Western Algeria, Journal of Medicinal Plants Research 6 (2012) 2041-2050. DOI: 10.5897/JMPR11.1796

[6]. H. Edziri, M. Mastouri, M.A. Mahjoub, Z. Mighri, A. Mahjoub, L. Verschaeve, Antibacterial, antifungal and cytotoxic activities of two flavonoids from Retama raetam flowers, Molecules 17 (2012) 7284-7293. https://doi.org/10.3390/molecules 17067284

[7]. H. Edziri, M. Mastouri, I. Chéraif, M. Aouni, Chemical composition and antibacterial, antifungal and antioxidant activities of the flower oil of Retama raetam (Forssk.) Webb from Tunisia, Natural Product Research 24 (2010) 789796. DOI: 10.1080/14786410802529190

[8]. J.M. Merillon, K. Ramavat, Co-Evolution of Secondary Metabolites, Springer Nature, Switzerland AG, 2018. DOI: 10.1007/978-3-31996397-6

[9]. J. Bruneton, Pharmacognosie, Phytochimie, Plantes médicinales, $2^{\text {éme }}$ ed., Tec et Docum, Paris, 1999.

[10]. R. Paris, H. Moyse, Précis de matière médicinale, Masson, Paris, 1969.

[11]. G.E. Trease, W.C. Evans, Pharmacognosy. $13^{\text {th }}$ Ed., Bellaire Tindall, London, 1989.

[12]. A. Chouikh, M. Mekki, E.H. Adjal, Effects of extraction methods on antibacterial activity of different extracts of Calligonum comosum L'her. growing in Sahara Algerian, International Journal of Recent Scientific Research 6 (2015) 3534-3536. 
[13]. F. Bekkara, M. Jay, M.R. Viricel, S. Rome, Distribution of phenolic compounds within seed and seedlings of tow Vicia faba cvs differing in their seed tannin content, and study of their seed and root phenolic exudation, Journal Plant and Soil 203 (1998) 27-36.

https://doi.org/10.1023/A:1004365913726

[14]. S.Y. Zhang, C.G. Zheng, X.Y. Yan, W.X. Tian, Low concentration of condensed tannins from catechu significantly inhibits fatty acid synthase and growth of MCF-7 cells, Biochemical and Biophysical Research Communications 371 (2008) 654-658.

https://doi.org/10.1016/j.bbrc.2008.04.062

[15]. V.L. Singleton, J.A. Rossi, Colorimetry of total phenolics with phosphomolybdic-phosphotungstic acid reagents, American Journal of Enology and Viticulture 16 (1965) 144-158.

[16]. A.A.L. Ordonez, J.D. Gomez, M.A. Vattuone, M.I. Isla, Antioxidant activities of Sechium edule (Jacq.) Swartz extracts, Food Chemistry 97 (2006) 452-458. https://doi.org/10.1016/j.foodchem.2005.05.024

[17]. A. Chouikh, F. Alia, S. Neffar, A. Rebiai, E. Adjal, A. Chefrour, Evaluation of phenolic contents (quantitative and qualitative) and antioxidant activities in different physiological phases of Genista saharae Coss. \& Dur. growing in the Sahara of Algeria, Analele Universităţii din Oradea Fascicula Biologie 25 (2018) 115-121.

[18]. W. Brand-Williams, M.E. Cuvelier, C. Berset, Use of a free radical method to evaluate antioxidant activity, LWT-Food Science and Technology 28 (1995) 25-30. https://doi.org/10.1016/S00236438(95)80008-5

[19]. Y. Khelef, A. Chouikh, A. Rebiai, S. Neffar, A. Chefrour, E.H. Adjal, F. Alia, Biochemical, quantitative and qualitative phenolic compounds, anti-free radical's activities of Calligonum comosum collected from different sites in the Algerian Desert, Biharean Biologist 13 (2019) 7176.

[20]. E. Bouchouka, A. Djilani, A. Bakkouche, Antibacterial and antioxidant activities of three endemic plants from Algerian Sahara, Acta Scientiarum Polonorum Technologia Alimentaria 11 (2012) 61-65.

[21]. V.V. Lévy-Frébault, F. Portaels, Proposed minimal standards for the genus Mycoterium and for description of a new slowly growing Mycobacterium species, International Journal of Systematic Bacteriology 42 (1992) 315-323. DOI: 10.1099/00207713-42-2-315

[22]. A. Chouia, A. Chouikh, F. Alia, E.H. Adjal, A. Chefrour, Y. Ait Kaki, Antibacterial activity and $\mathrm{DPPH} \bullet$ radical scavenging of differents metabolites extracted from two plants: essential oil from (Matricaria recutita L.) and flavonoids from flowers and leaves of (Hibiscus rosa-sinensis L.), Analele Universităţii din Oradea Fascicula Biologie 25 (2018) 26-32.

[23]. N. Gherairia, S. Boukerche, A. Chouikh, S. Khoudir, A. Chefrour, Antibacterial activity of essential oils from two species of genus Thymus growing in different sites of North Eastern Algerian, Analele Universităţii din Oradea Fascicula Biologie 26 (2019) 100-104.

[24]. L. Neto, A. Uchoa, A. Moura, B. Filho, G. Tenorio, A. Gomse, R. Ximenes, M. Vanusa, M.T. Correia, Phytochemical screening, total phenolic content and antioxidant activity of some plants from Brazilian flora, Journal of medicinal Plants Research 10 (2016) 409-416. https://doi.org/10.5897/JMPR2015.5979

[25]. B.N. Timmermann, C. Steelin, F.A. Loewus, Phytochemical Adaptations to Stress, CA Plenum Press, New York, 1984.

[26]. T. Dieu-Hien, N. Dinh-Hieu, A.T. Nhat-Thuy, B. Anh-Vo, H.D. Tuong, N. Hoang-Chinh, Evaluation of the use of different solvents for phytochemical constituents, antioxidants, and in vitro anti-inflammatory activities of Severinia buxifolia, Journal of Food Quality (2019) ID 8178294.

[27]. S. Guettaf, N. Abidli, S. Kariche, L. Bellebcir, H. Bouriche, Phytochemical screening and antioxidant activity of aqueous extract of Genista saharae (Coss. \& Dur.), Der Pharmacia Lettre 8 (2016) 50-60.

[28]. N. Ghedadba, L. Hambaba, M.C. Ayachi, H. Aberkane, S.M. Bousselsela, S.M. Oueld Moukhtar, Polyphénols totaux, activités antioxydant et antimicrobienne des feuilles de Marrubium deserti de Noé, Phytothérapie 13 (2015) 118-129. https://doi.org/10.1007/s10298015-0944-4

[29]. E. Hayouni, M. Abedrabba, M. Bouix, M. Hamdi, The effects of solvent and extraction method on the phenolic contents and biological activities in vitro of Tunisian Quercus coccifera L. and Juniperus phoenicea L. fruit extracts, Food Chemistry 105 (2007) 1126-1134. https://doi.org/10.1016/j.foodchem.2007.02.010

[30]. D. Atmani, N. Chaher, M. Berboucha, K. Ayouni, H. Lounis, H. Boudaoud, N. Debbache, D. Atmani, Antioxidant capacity and phenol content of selected Algerian medicinal plants, Food Chemistry 112 (2009) 303-309. https://doi.org/10.1016/j.foodchem.2008.05.077

[31]. D.L. Luthria, Influence of experimental conditions on the extraction of phenolic compounds from parsley (Petroselinum crispum) flakes using a pressurized liquid extractor, Food Chemistry 107 (2008) 745-752. https://doi.org/10.1016/j.foodchem.2007.08.074

[32]. E. Marco, S. Maria, P. Antonello, S. Raffaele, Characterization and fractionation of phenolic compounds extracted from olive oil mill wastewaters, Food Chemistry 104 (2007) 858-867. https://doi.org/10.1016/j.foodchem.2006.10.005

[33]. F. Visioli, A. Romani, N. Mulinacci, S. Zarini, D. Conte, F. Vincieri, Antioxidant and other biological activities of olive mill waste waters, Journal of Agricultural and Food Chemistry 47 (1999) 3397-3401. https://doi.org/10.1021/jf9900534 
[34]. E. Marinova, A. Toneva, N. Yanishlieva, Comparison of the antioxidative properties of caffeic and chlorogenic acids, Food Chemistry 114 (2009) 1498-1502.

DOI: 10.1016/j.foodchem.2008.11.045

[35]. M.R. Ahn, S. Kumazawa, Y. Usui, J. Nakamura, M. Matsuka, F. Zhu, Antioxidant activity and constituents of propolis collected in various areas of China, Food Chemistry 101 (2007) 1383-1392. https://doi.org/10.1016/j.foodchem.2006.03.045

[36]. M. Debouba, R. Balti, S. Hwiwi, S. Zouari, Antioxidant capacity and total phenols richness of Cistanche violacea hosting Zygophyllum album, International Journal of Phytomedicine 4 (2012) 399-402.

[37]. F. Pourmorad, S.J. Hosseinimehr, N. Shahabimajd, Antioxidant activity, phenol and flavonoid contents of some selected Iranian medicinal plants,
African Journal of Biotechnology 5 (2006) 11421145 .

[38]. K. Ivana, N. Milena, L. Miodrag, Comparison of antioxidant and antimicrobial activities of methanolic extracts of the artemisia sp. recovered by different extraction techniques, Chinese journal of chemical engineering 19 (2011) 504-511. https://doi.org/10.1016/S1004-9541(11)60013-X

[39]. P.A. Lambert, Cellular impermeability and uptake of biocides and antibiotics in Gram-positive bacteria and mycobacteria, Journal of Applied Microbiology 92 (2002) 46-54.

https://doi.org/10.1046/j.1365-2672.92.5s1.7.x

Received: 11.11 .2020

Received in revised form: 20.02.2021

Accepted: 22.02.2021 